\title{
The Extent of Environmental Responsibility in Korea's Top Ten Five-Star Hotels
}

\author{
Sung-Wook Kang ${ }^{1} \&$ Song-Ee Hahn ${ }^{2}$ \\ ${ }^{1}$ Department of International Business and Asian Studies, Griffith University, Parkland Drive South Port QLD, \\ Australia \\ ${ }^{2}$ Department of Tourism, Sport and Hotel Management, Griffith University, Parkland Drive South Port QLD, \\ Australia \\ Correspondence: Sung-Wook Kang, Department of International Business and Asian Studies, Griffith University, \\ Parkland Drive South Port QLD, Australia. E-mail: michael.kang@griffithuni.edu.au
}

Received: August 25, 2014

Accepted: September 10, 2014

Online Published: October 22, 2014

doi:10.5539/ijbm.v9n11p13

URL: http://dx.doi.org/10.5539/ijbm.v9n11p13

\begin{abstract}
This paper will provide a snapshot of the level of environmental responsibility of Korean top ten five-star hotels in relation to their environmental disclosures. Content analysis is employed to review the environmental disclosures of the top ten hotels in Korea, as defined herein. This study found that the level of environmental responsibility of Korea's leading hotels lags behind the standard global environmental hotel practices in many ways. Consequently, many improved environmental practices need to be implemented by these sampled hotels.
\end{abstract}

Keywords: environmental disclosure, proactive environmental strategy, tourism and hospitality

\section{Introduction}

Environmental protection and the need for sustainability has become a vital priority in the business world during the last few decades and the tourism and hospitality industry is not an exception (Bohdanowicz \& Zientara, 2012; Matute \& Melero, 2015; Shah, 2011). Environmental responsibility has become a serious strategic issue for the global hotel industry. In line with this context, an increasing number of hotels have begun to implement various proactive environmental actions in terms of reducing - such as in areas of Green House Gas emissions (GHG), water and energy consumption; recycling - for example for paper, plastics, glass bottles; reusing treated water and recycled products (Brown, 1996; Claver-Cortes, Molina-Azorin, Pereira-Moliner \& Lopez-Gameo, 2007; Murillo-Luna, Garces-Ayerbe \& Rivera-Torres, 2011); and also publicizing their environmental endeavours by way of website disclosure, sustainability reports and corporate social responsibility reports.

Currently, the Korean tourist market is substantial and continually growing. About twelve million international tourists visited Korea in 2013, ranking it fourth in the number of inbound international tourist in the Asia Pacific region (UNWTO website, July 2014). This study is motivated by the authors' concerns, as well as the fact that environmental responsibility has become a major international issue and has been accompanied by substantial and growing stakeholder concerns (Cho, Guidry, Hageman \& Patten, 2012). This concern has led the authors to evaluate how Korea's leading hotels are responding to their environmental responsibilities. Consequently, this study has a twofold objective and focuses on answering the following two propositions:

1). Which environmental factors have received greatest attention from the leading hotels in Korea?

2). To what extent has Korea's leading hotels met their environmental responsibilities by proactively implementing appropriate strategies?

At present there has been little attention paid to these research questions which focus on how, and to what extent, top lodging operators report their environmental initiatives in the public domain (Hsieh, 2012). The purpose of this study is to investigate the level of environmental responsibility of the top ten Korean five star hotels which are registered with the Korean Tourism Organisation (KTO) and the study makes several contributions to the current body of knowledge. It provides guidelines to hotels who want to initiate environmental responsibility and scholars who want to start research in this area. Also, policy makers can use this article to develop their understanding of the hotel sector's environmental responsibility. 


\section{Literature Review}

Even though the environmental impacts of the hotel sector are relatively minor compared to those of the manufacturing or chemical sector, which are widely seen as the heavy polluters, an increasing number of hotels have engaged in incorporating and institutionalizing sustainability into their practices which the aim of cultivating green operations (Han, Hsu \& Sheu, 2010). At present, both small and large hotel operators aim to disclose their environmental endeavours to the public, although the implementation levels of environmental practice are different (Villers \& Staden, 2011).

Many researchers believe that hotels can benefit from publicizing their environmental responsibility practices because it can increase their legitimacy in the wider world and facilitate the construction of a new and improved image of the company (Hopwood, 2009). In addition, it is also believed that hotel's that display their environmental responsibility through proactive environmental programs can generate a competitive advantage and improved environmental performance (Leonidou, Leonidou, Fotiadis \& Zeriri, 2013).

Further, the literature also suggests that stakeholder pressure (internal and external) is an important trigger regarding a hotel's appreciation of their environmental responsibility (Lopez-Gamero, Molina-Azorin \& Claver-Cortes, 2011). The motivation to implement environmental practices comes from external stakeholder pressure which can be passive in nature and posits that the costs of environmental investments are often less than the benefits achieved (Clarkson, Richardson \& Vasvari, 2011). Hotels which are motivated by external stakeholder pressure may consider that stakeholders' environmental expectations are a driver for hotels developing environmental responsibility practices (Garces-Ayerbe, Rivera-Torres \& Murillo-Luna, 2012).

On the other hand, the resource based view (RBV) argues that firms voluntarily implement environmental program because firms can build competitive advantage by strategically leveraging their resources and in turn, this results in superior performances in the long term (Leonidou, Leonidou, Fotiadis \& Zeriti, 2013). RBV predicts that firms with strong environmental resources and capabilities would adopt a proactive approach, while firms with weak environmental capabilities would most likely embrace a reactive posture (Hart \& Dowell, 2010).

Depending on the firm's environmental strategic position, hotels can adopt a wide range of environmental strategies. Based on previous research, environmental strategy can be categorized into two groups: reactive and proactive (Aragon-Correa \& Sharma, 2003; Hart, 1995; Russo \& Fouts, 1997). Still, the motivations towards achieving environmental responsibility are controversial and debate persists in academia as every hotel has its own specific conditions.

This study adopts Sharma and Vredenburg's (1998, p. 773) definition which considers a firm's environmental strategy to be proactive when it conducts "a consistent pattern of environmental practices, across all dimensions relevant to their range of activities, not required to be undertaken in fulfilment of environmental regulation or in response to isomorphic pressure within the industry as standard business practice". However, a firm is considered to have a reactive environmental strategy when it acts on environmental problems as they occur and in response to internal, or more likely, external pressure (Aragon-Correa, 2008). Reactive environmental strategy is often recognized in previous literature as a compliance strategy, wherein firms rely on pollution reduction through an "end of pipe" approach, often resisting the environmental legislation. Whereas firms which have a proactive environmental strategy go beyond compliance by focusing on prevention, and implementing a systemic approach that emphasizes source reduction and process innovation (Murillo-Luna et al., 2011).

Since hotels' intentions to convey better environmental responsibility cannot be directly observed and thus easily measured, this study uses the level of environmental disclosure as a proxy (Park \& Kim, 2014). Therefore, this study assumes that firms with comprehensive and abundant environmental practices are more likely to disclose their environmental endeavours to the public and accordingly there is a high level of environmental responsibility proactivness.

\section{Methodology}

In order to investigate the current level of environmental responsibility of five star hotels in Korea, this research collected related secondary data from study samples drawn from the Korea Tourism Organization (KTO) (2013). According to KTO (2013), there are 71 five star hotels registered in Korea. The current research selected the top ten five star hotels by room number as research samples (see Table 1 for the selected sample hotels) based on KTO's list of registered hotels in 2013. This is because these top ten hotels represent the leading hotel groups in Korea (Yoo, 2010). 
Table 1. Top ten five-star hotel companies

\begin{tabular}{lc}
\hline Company & Number of rooms \\
\hline Hotel Lotte & 1,151 \\
Wakerhill Hotel & 930 \\
Kangwonland Hotel \& Casino & 727 \\
Millenium Seoul Hilton & 679 \\
Intercontinental Seoul Coex & 654 \\
Grand Hyatt Seoul & 601 \\
Jeju Grand Hotel & 512 \\
Grand Hilton Seoul & 503 \\
Seoul Shilla Hotel & 461 \\
The Westin Chosun Seoul & 453 \\
\hline
\end{tabular}

Source: Korea Toursim Organizaiton (KTO).

This study collected the secondary data published by the ten selected Korean hotel companies regarding their environmental policies, practice and information in June 2014. The researchers first visited the websites of the ten hotel companies, then carefully examined their annual reports, sustainability reports and/other related website contents. The data analysis was conducted using content analysis which is useful for investigating whether certain concepts and words exist within content (Gray, Kouhy \& Lavers, 1995). The current research also synthesized previous studies in the environment management literature (e.g. Anderson, 2003; Corral-Verdugo, 1996; Ross \& Evans, 2003; Wei \& Huang, 2001) and adopted a classification scheme to evaluate the environmental responsibility of the hotel companies, including the following three factors: reduce, recycle and reuse. The researchers coded the data using three factors comprising of eight sub-categories: A) sustainability report; B) GHG emissions; C) water; D) energy consumption; E) water (recycle); F) solid waste; G) treated water; H) recycled product. These sub-categories were sourced from the Global Initiative Guideline 3.0 (GRI) and reorganized by the authors (Hawkins, 2012). The coded data was peer reviewed in order to ensure the reliability and validity of the study results.

\section{Findings}

As seen in Table 2, eight hotels disclosed some environmental data to the public and three hotels disclosed no data (Hotel Lotte, Jeju Grand Hotel, Seoul Shilla Hotel). Table 2 also shows that most of the Korean top ten hotels focus on environmental reduction activities, which include reducing GHG emissions, water and energy consumption.

After a comprehensive evaluation of the criteria in Table 2, the study sample was divided into two groups labelled 'proactive' or 'reactive'. The proactive group include Kangwonland Hotel \& Casino, Intercontinental Seoul Coex, The Westin Chosun Seoul and Grand Hyatt Seoul. The reactive group included Wakerhill Hotel, Millenium Seoul Hilton, Grand Hilton Seoul, Hotel Lotte, Jeju Grand Hotel and Seoul Shilla Hotel (See Figure $1)$. 
Table 2. Summary of environmental public disclosure of the Korean top ten five-star hotel companies

\begin{tabular}{|c|c|c|c|c|c|c|c|c|}
\hline \multirow[b]{2}{*}{ Company } & \multicolumn{4}{|c|}{ Reduce } & \multicolumn{2}{|c|}{ Recycle } & \multicolumn{2}{|c|}{ Reuse } \\
\hline & A & $\mathrm{B}$ & $\mathrm{C}$ & $\mathrm{D}$ & $\mathrm{E}$ & $\mathrm{F}$ & G & $\mathrm{H}$ \\
\hline \multicolumn{9}{|l|}{ 1. Hotel Lotte } \\
\hline 2. Wakerhill Hotel & & & $\sqrt{ }$ & $\sqrt{ }$ & & $\sqrt{ }$ & & \\
\hline 3. Kangwonland Hotel \& Casino & $\sqrt{ }$ & $\sqrt{ }$ & $\sqrt{ }$ & $\sqrt{ }$ & $\sqrt{ }$ & $\sqrt{ }$ & $\sqrt{ }$ & $\sqrt{ }$ \\
\hline 4. Millenium Seoul Hilton & & $\sqrt{ }$ & $\sqrt{ }$ & $\sqrt{ }$ & & & & \\
\hline 5. Intercontinental Seoul Coex & & $\sqrt{ }$ & & & & $\sqrt{ }$ & $\sqrt{ }$ & \\
\hline 6. Grand Hyatt Seoul & & $\sqrt{ }$ & $\sqrt{ }$ & $\sqrt{ }$ & & & & \\
\hline \multicolumn{9}{|l|}{ 7. Jeju Grand Hotel } \\
\hline 8. Grand Hilton Seoul & & $\sqrt{ }$ & $\sqrt{ }$ & $\sqrt{ }$ & & & & \\
\hline \multicolumn{9}{|l|}{ 9. Seoul Shilla Hotel } \\
\hline 10. The Westin Chosun Seoul & & $\sqrt{ }$ & $\sqrt{ }$ & $\sqrt{ }$ & & & & \\
\hline
\end{tabular}

Note. A: Sustainable Report; B: Green House Gas emission; C: water; D:energy consumption; E: water; F: solid waste; G: treated water; H: Recycled product.

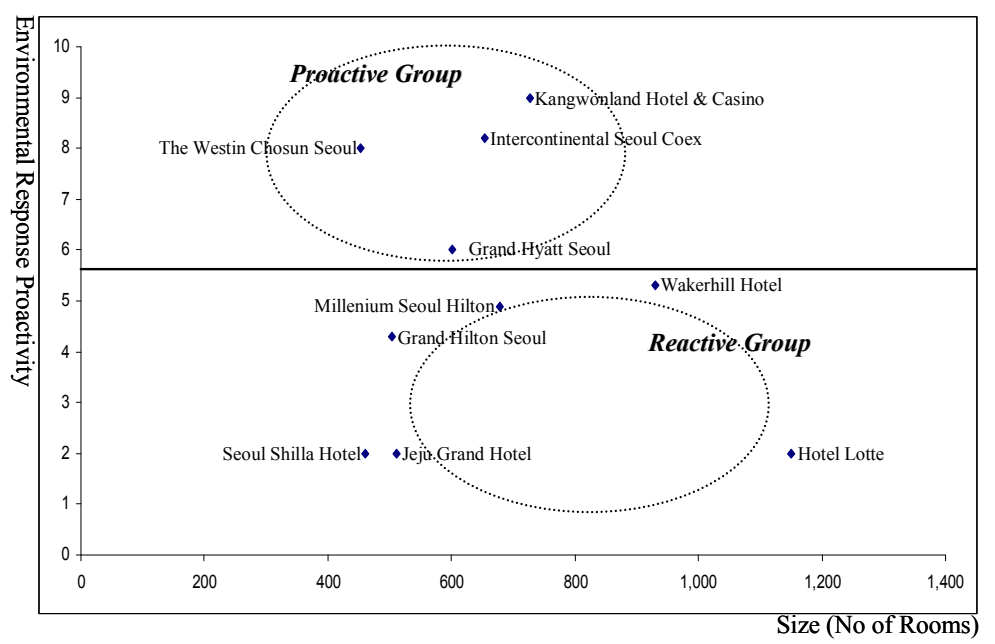

Figure 1. Proactiveness of environmental responsibility in sampled hotels

\subsection{Four Hotel Companies Displaying Proactive Environmental Reporting}

\subsubsection{Kangwonland Hotel \& Casino-The Only Hotel with a Sustainability Report}

- General outlook: Kangwonland Hotel \& Casino was the only company among our sampled hotels which had a published sustainability report. Kangwonland was established in June 29, 1998 as a casino and resort, and had assets of USD 2.7 billion and sales of USD 1.2 billion in 2013.

- Environmental programs undertaken by Kangwonland Hotel \& Casino: The hotel acquired international environmental certification (ISO9001 and ISO14001) in January 2011. In 2011, it set up environmental management policies and processes for stakeholders (internal/external). It's key environmental management practices are recognized as: (1) systemic water management; (2) minimization of domestic waste; (3) innovative environmental education; and (4) reduction of energy consumption.

- Environmental performance / competitive advantage: Kangwonland Hotel \& Casino increased its environmental investment by approximately three times between the years 2009 to 2011. In terms of specific examples of improved environmental performance, diesel consumption decreased from 734KL to $391 \mathrm{KL}$ and the use of recycled water increased from $62,388 \mathrm{~m}^{2}$ to $99,054 \mathrm{~m}^{2}$. 
Table 3. Environmental achievement by Kangwonland Hotel \& Casino

\begin{tabular}{llll}
\hline & Unit & 2012 & 2011 \\
\hline Direct energy consumption & Diesel, KL & 391 & 734 \\
Total water used for re-use and recycling & $\mathrm{m}^{2}$ & 99,054 & 62,388 \\
Total investment on environment & USD & $1,326,300$ & 336,600 \\
Amount of green products purchased & USD & 504,000 & 381,000 \\
Introduction of LED & EA & 5,800 & 4,204 \\
\hline
\end{tabular}

Source: Kangwonland Hotel \& Casino Sustainablility Reprot (2013).

\subsubsection{Intercontinental Seoul Coex - A Hotel with a Large Environmental Investment}

- General outlook: Intercontinental Seoul Coex is an affiliated hotel of the Intercontinental Hotel Group. Intercontinental Seoul Coex was established in 1985 and recorded sales of USD 22 million in 2012.

- Environmental programs taken by Intercontinental Seoul Coex: The Intercontinental Hotel Group has a unique sustainability system called 'Green Engage' for affiliated hotels. This program has been adopted by Intercontinental Seoul Coex and has five pillars: (1) carbon and energy; (2) water; (3) waste; (4) biodiversity; and (5) supply chain, for example: (1) LED lightning installation in order to save electrical energy; (2) storage and use of off-peak (night) electricity; and (3) hiring of three full time employees for its recycling process.

- Environmental performance / competitive advantage: Intercontinental Seoul Coex is the only hotel among the Korean five star hotels which has acquired a 'Bronze level' from the Green Globe. Green Globe is one of the reputable international organizations which issues environmental certification. To obtain an issuing certificate, Green Globe comprehensively addresses the candidate hotel's sustainability performance in terms of sustainable management aspects, social/economic aspects, cultural heritage aspects and environmental aspects. Additionally, Intercontinental Seoul Coex installed a grey water system in 2009 which enables up to 50 per cent of waste water to be returned to the hotel. Treated grey water is used for toilet flushing and cleaning purposes. The cost recovery time for the grey water system was recorded approximately three years after installation.

\subsubsection{The Westin Chosun Seoul - A Proactive Environmental Attitude}

- General outlook: The Westin Chosun Seoul is an affiliated hotel of Starwood Hotel \& Resort Worldwide. The Westin Chosun Seoul was established in 1970 and recorded sales of USD 22 million in 2012. The Westin Chosun is located in the heart of South Korea's capital city and is within walking distance of several historic landmarks such as Blue House, City Hall, Cheonggyecheon Stream, and Gwanghwamun Plaza.

- Environmental programs undertaken by The Westin Chosun Seoul: The Westin Chosun Seoul conducts comprehensive environmentaly friendly programs which include: (1) purchasing local food for the dining; (2) planting trees for eco-diversity; (3) Creating a linen/towel re-use program (called 'Green Card'); (4) use of environmentally friendly products for guest rooms; (5) installing energy efficient facilities; (6) environmental training for employees.

- Environmental performance / competitive advantage: From 2008 to present, the Westin Chosun Seoul has invested in high energy efficient facilities including heat pumps, heat exchangers and boilers. Gross savings from these investments have been estimated at USD 100,000 per year.

\subsubsection{Grand Hyatt Seoul - Global Standard Environmental Policy}

- General outlook: The Grand Hyatt Seoul is an affiliated hotel of Global Hyatt Corporation. Grand Hyatt Seoul was established in 1978 and recorded sales of approximately USD 25 million in 2012. The Grand Hyatt Seoul is located in the Yongsan district and has 601 luxury rooms.

-Environmental programs undertaken by Grand Hyatt Seoul: The Grand Hyatt has an environmental program named 'THRIVE Initiatives' which is designed to reduce the environmental impact of hotel operations. The THRIVE Initiatives address the areas of: (1) environmental awareness, education and training for employees and guests; (2) waste reduction; (3) energy conservation; (4) water conservation; (5) sustainable purchasing policy; and (6) eco-friendly chemical use. The Grand Hyatt Seoul has adopted the THRIVE Initiatives for its environmental program.

-Environmental performance / competitive advantage: The Grand Hyatt Seoul achieved USD 100,000 in savings with the replacement of energy efficient electronic thermostats and a heated water exchanger. 


\subsection{Three Hotel Companies Which Demonstrate Reactive Environmental Reporting}

\subsubsection{Wakerhill Hotel - Global Hotel Brand Affiliation}

The Wakerhill Hotel is an affiliated hotel of Starwood Hotel \& Resort Worldwide.

- Environmental guidelines offered by affiliated hotels: Starwood Hotel \& Resort Worldwide provides environmental guidelines for affiliated hotels. These environmental guidelines include: (1) conserving natural resources; (2) minimizing waste and pollution; (3) enhancing indoor environmental quality; (4) establishing and reporting on key environmental performance indicators; and (5) raising environmental awareness among associates, guests and communities. Wakerhill Hotel has adopted some of these guidelines.

- Environmental actions undertaken by Wakerhill Hotel: The Hotel operates a voluntary linen/towel re-use program for customers who stay more than two days. Also, in conjunction with a recycling program, all the hotel wood scraps are collected and sent to local residents for fuel.

\subsubsection{Millenium Seoul Hilton - Global Hotel Brand Affiliation}

The Millenium Seoul Hilton is an affiliated hotel of Hilton Worldwide.

- Environmental guidelines offered by affiliated hotels: Hilton Worldwide announced a goal of environmental commitment in 2009, which was expected to be achieved by 2014. This is considered a short term and measureable target. The goal of the short term targets is to reduce four categories: (1) energy consumption (20\%); (2) CO2 emission (20\%); (3) waste output (20\%); and (4) water consumption (10\%). In addition to this, Hilton Worldwide has set long term targets which include sustainable design and construction, sustainable hotel operations, clean chemical management and eco-friendly purchasing.

- Environmental programs have been delivered by Millenium Seoul Hilton: The hotel also follows some of Hilton Worldwide's environmental policy guidelines. Seoul Hilton has adopted a linen/towel re-use program which is named 'Green Card'. Currently, one thousand customers per month participated in this program. This hotel is also gradually replacing older equipment to energy efficient equipment (commercial refrigerators \& air cleaners).

\subsubsection{Grand Hilton Seoul - Global Hotel Brand Affiliation}

The Grand Hilton Seoul is an affiliated hotel of Hilton Hospitality Inc.

- Environmental guidelines offered by affiliated global hotel brands: See 4.2.2.

- Environmental programs implemented by the Grand Hilton Seoul: The Grand Hilton Seoul has acquired 'Certificate of Eco Tourism' from TUV Rheinland Korea in 2009. TUV Rheinland is a German-based international consulting group which covers various areas including environmental certification. The Grand Hilton Seoul has received high scores from TUV Rheinland in the areas of energy, waste, water and chemical substances.

\section{Conclusion \& Discussion}

This study has taken a broad look at the current state of environmental responsibility and analysed the environmental data of the top ten five star hotels in Korea. In this section this study will point out four major topics from our findings.

First, the general level of environmental responsibility is low in the top ten five star hotels in Korea. Eccles and Serafeim (2011) conducted cross country studies (23 countries, 2,000 firms) to distinguish between leading and lagging countries in contributing to a sustainable society. Korea was categorised as an unsustainable country with China and Hong Kong as there is very little integrated reporting by companies and very little interest by investors in non-financial performance. Our finding is consistent with this research. This study found that only one hotel among our sampled hotels has published a stand alone sustainable report (Kangwonland Hotel \& Casino) even though these are considered leading hotel groups in Korea. This result indicates that the sampled hotels do not voluntarily disclose their environmental information as the level of stakeholder (customer / investor) interest for environmental responsibility is low in Korea.

Second, environmental responsibility disclosure in sampled hotel websites was poor. Websites provide an effective platform to develop brand image and communicate environmental commitment to stakeholders (Hsieh, 2012). Hsieh (2012) found 46 percent of the world's 50 top hotels include environmentally related information on their websites. However, in this study, few hotels were found to disclose environmental information on their websites. Korean hotels should utilize the unique advantage of the internet to present their environmental endeavours. 
Third, the top ten five-star hotels in Korea mainly focus on GHG emissions, water and energy consumption which are related to short term saving activities. Under the short-term performance driven culture of Korean management practice, the sample hotels rarely consider long-term environmental investment which requires large funds and long cost recovery time. In addition, as the sample hotels have a narrow focus, consequently, they frequently ignore some important environmental activities. Therefore, Korean hotels should adopt a longer term view in regard to environmental responsibility as well as more comprehensive environmental programs at the benchmarking standard of global leading hotel groups.

Fourth, our findings indicate that even though leading global hotels (Intercontinental Hotel Group, Hilton Worldwide, Starwood and Global Hyatt Corporation) have well established environmental policies and regulations, the global affiliated hotels in our sample do not emphasize these. This study had difficulty finding the established policies and regulations of global leading hotels in the sampled global affiliated hotels. Therefore, Korean hotels are recommended to benchmark and institutionalize these global environmental standards to learn how leading hotels implement environmental practices.

This study has several limitations and gives suggestions for future studies. First, it is difficult to generalise the findings to all hotel companies as this study did not address all hotels in Korea. Future research could include a larger sample to increase validity. Second, this study used secondary data; therefore there is a possibility of data omission, even though the researchers are confident there is no significant missing data which would change the findings of this study. Future research could also include surveys and interviews in their methodology in order to achieve further insight into the issue of hotel environmental responsibility disclosure.

\section{References}

Anderson, J. (2003). The environmental benefits of water recycling and reuse. Water Supply, 3(4), 1-10.

Aragon-Correa, J. A., \& Sharma, S. (2003). A contingent resource-based view of proactive corporate environmental strategy. Academy of Management Review, 28(1), 71-88. http://doi.dx.org/10.5465/AMR.2003.8925233

Aragón-Correa, J. A., Hurtado-Torres, N., Sharma, S., \& García-Morales, V. J. (2008). Environmental strategy and performance in small firms: A resource-based perspective. Journal of Environmental Management, 86(1), 88-103. http://doi.dx.org/10.1016/j.jenvman.2006.11.022

Brown, M. (1996). Environmental policy in the hotel sector: "green" strategy or stratagem? International Journal of Contemporary Hospitality Management, 8(3), 18-23.

Clarkson, P. M., Li, Y., Richardson, G. D., \& Vasvari, F. P. (2011). Does it really pay to be green? Determinants and consequences of proactive environmental strategies. Journal of Accounting and Public Policy, 30(2), 122-144. http://doi.dx.org/10.1016/j.jaccpubpol.2010.09.013

Claver-Cortés, E., Molina-Azorín, J. F., Pereira-Moliner, J., \& López-Gamero, M. D. (2007). Environmental strategies and their impact on hotel performance. Journal of Sustainable Tourism, 15(6), 663-679. http://doi.dx.org/10.2167/jost640.0

Cho, C. H., Guidry, R. P., Hageman, A. M., \& Patten, D. M. (2012). Do actions speak louder than words? An empirical investigation of corporate environmental reputation. Accounting, Organizations and Society, 37(1), 14-25. http://doi.dx.org/10.1016/j.aos.2011.12.001

Corral-Verdugo, V. (1996). A structural model of reuse and recycling in Mexico. Environment and Behavior, 28(5), 665-696. http://doi.dx.org/10.1177/001391659602800505

Eccles, R. G., \& Serafeim, G. (2011). Leading and Lagging Countries in Contributing to a Sustainable Society. Harvard Business School Working Knowledge.

Gray, R., Kouhy, R., \& Lavers, S. (1995). Corporate social and environmental reporting: a review of the literature and a longitudinal study of UK disclosure. Accounting, Auditing \& Account Ability Journal, 8(2), 47-77. http://doi.dx.org/10.1108/09513579510146996

Garcés-Ayerbe, C., Rivera-Torres, P., \& Murillo-Luna, J. L. (2012). Stakeholder pressure and environmental proactivity: moderating effect of competitive advantage expectations. Management Decision, 50(2), 189-206. http://doi.dx.org/10.1108/00251741 211203524

Han, H., Hsu, L. T. J., \& Sheu, C. (2010). Application of the theory of planned behavior to green hotel choice: Testing the effect of environmental friendly activities. Tourism Management, 31(3), 325-334. http://doi.dx.org/0.1016/j.tourman.2009.03.013 
Hart, S. L. (1995). A natural-resource-based view of the firm. Academy of Management Review, 20(4), 986-1014. http://doi.dx.org/10.5465/AMR.1995.9512280033

Hart, S. L., \& Dowell, G. (2010). A natural-resource-based view of the firm: Fifteen years after. Journal of Management. http://doi.dx.org/10.1177/01492063 10390219

Hawkins, R., \& Bohdanowicz, P. (2012). Responsible hospitality: Theory and practice. Oxford: Good fellow Publishers.

Hopwood, A. G. (2009). Accounting and the environment. Accounting, Organizations and Society, 34(3), 433-439. http://doi.dx.org/10.1016/j.aos.2009.03.002

Hsieh, Y. C. J. (2012). Hotel companies' environmental policies and practices: a content analysis of their web pages. International Journal of Contemporary Hospitality Management, 24(1), 97-121. http://doi.dx.org/10.1108/095961112

KTO. (2014). Visitor Arrivals, Korean Departures, Int'1 Tourism Receipts \& Expenditures. Retrieved from http://kto.visitkorea.or.kr/eng/tourismStatics/keyFacts/visitorArrivals.kto

Leonidou, L. C., Leonidou, C. N., Fotiadis, T. A., \& Zeriti, A. (2013). Resources and capabilities as drivers of hotel environmental marketing strategy: Implications for competitive advantage and performance. Tourism Management, 35, 94-110. http://doi.dx.org/10.1016/j.tourman.2012. 06.003

López-Gamero, M. D., Molina-Azorín, J. F., \& Claver-Cortes, E. (2011). The relationship between managers' environmental perceptions, environmental management and firm performance in Spanish hotels: a whole framework. International Journal of Tourism Research, 13(2), 141-163. http://doi.dx.org/10.1002/jtr.805

Murillo-Luna, J. L., Garcés-Ayerbe, C., \& Rivera-Torres, P. (2011). Barriers to the adoption of proactive environmental strategies. Journal of Cleaner Production, 19(13), 1417-1425. http://doi.dx.org/10.1016/j.jclepro.2011.05.005

Park, J., \& Kim, H. J. (2014). Environmental proactivity of hotel operations: Antecedents and the moderating effect of ownership type. International Journal of Hospitality Management, 37, 110. http://doi.dx.org/10.1016/j.ijhm.2013.09.011

Ross, S., \& Evans, D. (2003). The environmental effect of reusing and recycling a plastic-based packaging system. Journal of Cleaner Production, 11(5), 561-571. http://doi.dx.org/10.1016/ S0959-6526(02)00089-6

Russo, M. V., \& Fouts, P. A. (1997). A resource-based perspective on corporate environmental performance and profitability. Academy of Management Journal, 40(3), 534-559. http://doi.dx. org/10.2307/257052

Sharma, S., \& Vredenburg, H. (1998). Proactive corporate environmental strategy and the development of competitively valuable organizational capabilities. Strategic Management Journal, 19(8), 729-753.

Kangwonland. (2013). Sustainability Report Kangwon land Hotel \& Casino. Retrieved from http://database.globalreporting.org/reports/view/19349

UNWTO. (2014). UNWTO World Tourism Barometer. Retrieved from http://mkt.unwto.org /en/barometer

Villiers, C. D., \& Van Staden, C. J. (2011). Where firms choose to disclose voluntary environmental information. Journal of Accounting and Public Policy, 30(6), 504-525. http://doi.dx.org/10.1016/j.jaccpubpol.2011.03.005

Wei, M. S., \& Huang, K. H. (2001). Recycling and reuse of industrial wastes in Taiwan. Waste Management, 21(1), 93-97. http://doi.dx.org/10.1016/S0956-053X(00)00073-8

Yoo, Y. J. (2010). Congruence between Actual/Social Self-Images, and Brand Images of Hotels-The Case of Top-Class Hotels in Seoul, Korea. Cultural Tourism Studies, 12(1), 71-81.

\section{Copyrights}

Copyright for this article is retained by the author(s), with first publication rights granted to the journal.

This is an open-access article distributed under the terms and conditions of the Creative Commons Attribution license (http://creativecommons.org/licenses/by/3.0/). 